\title{
THE UTILIZATION OF BAMBOO WASTE AS A NEW ALTERNATIVE MATERIAL IN THE AIRCRAFT FUSELAGE INTERIOR PANEL STRUCTURE
}

\author{
Lado Rislya Prakasa ${ }^{1}$, Mohamad Firmansyah ${ }^{2}$, Pandy Fitrian Al Hadi ${ }^{3}$, Kris \\ Hariyanto ${ }^{4}$ \\ 1,2,3,4 Departemen Teknik Dirgantara - Sekolah Tinggi Teknologi Adisutjipto Yogyakarta \\ ladoprakasa@gmail.com ${ }^{1}$,mohamcorp@gmail.com ${ }^{2}$,pandyfitrianalhadi@gmail.com ${ }^{3}$, \\ krishariyanto76@gmail.com ${ }^{4}$
}

\begin{abstract}
In the aircraft manufacturing industry, the strength and weight of the material is one of the important considerations in structural design. Composite material is a material composed of two or more forming materials, each of which has different mechanical properties. Aircraft structure in this era are 50 - 80\% composed of glass or carbon fiber composite materials as reinforcement. Unfortunately, these fibers when recycled produce harmful CO gas, difficult to degrade naturally and cause itching when in contact with human skin. For this reason, environmentally friendly and strong fibers are needed to replace the role of glass or carbon fibers. Is a bamboo plant, which is abundant in Indonesia which is considered suitable as a substitute material. In this study, a mechanical test and descriptive analysis were carried out on the strength of the composite material with variations in the types of bamboo fibers apus, wulung, tutul and petung. These fibers are arranged with epoxy resin and hardener as a binding material (matrix). And each fiber will be arranged in $0^{\circ}$ pattern to the matrix. Then each material with a different fiber type will be tested for tensile and bending to obtain the value of stress and strain that occurs at its maximum loading. And the result is the average tensile stress value (Mpa) composite material of apus bamboo is 75.95, wulung bamboo 49.92, petung bamboo 112.73, tutul bamboo 83.85. Then the average bending stress (Mpa) composite material of apus bamboo was 239.073, wulung bamboo 214.236, petung bamboo 249.67, tutul bamboo 272.79. With this result, bamboo fiber composites are considered to be able to replace the role of carbon or glass fibers, as an alternative composite material in some parts of the interior fuselage of aircraft panels.
\end{abstract}

Keyword: Composites material, Matrix, Bamboo Fibers, Carbon and Glass Fibers, Stress and Strain.

\section{Latar Belakang}

Kekuatan dan berat menjadi prioritas utama dalam membangun sebuah pesawat terbang. Pada generasi awal pembuatan pesawat terbang, material utama penyusun struktur badan dan sayap pesawat terbang adalah kayu, kain katun, dan beberapa baja. Pada era tersebut kayu memang dikenal sebagai material yang cukup kuat dan ringan untuk menerbangakan benda di udara. Kemudian pada tahun 1919 - 1940 para perancang pesawat mulai menggunakan logam sebagai material penyusun struktur pesawat terbang. Logam yang digunakan adalah aluminium dan titanium murni ataupun aluminium dan titanium campuran dengan material lain. Dan hasilnya pada tahun 1927 ford 4-AT menjadi pesawat terbang pertama kali yang menggunakan material penyusun dari logam. Material logam dan kayu tersebut sering disebut sebagai material konvensional. Lalu pada tahun 1940 material komposit mulai familiar digunakan dalam manufaktur pesawat terbang untuk menggantikan peran dari material konvensional sebagai material penyusun. Material komposit adalah material yang tersusun dari 2 atau lebih 
material pembentuk yang masing - masing memiliki sifat mekanis yang berbeda. Banyak manufaktur pesawat terbang pada era ini menggunakan material komposit sebagai material utama penyusun struktur pesawat terbang, salah satunya seperti pesawat A-350 dari pabrikan Airbus dan B-787 dari pabrikan Boeing [1][2]. Material komposit secara masif diaplikasikan pada bagian eksterior seperti pada sambungan sayap dengan badan pesawat ( wing - body fairing ), wig tip, wing let, dan pada beberapa bagian di struktur luar dari badan, sayap dan sirip pesawat terbang. Selain pada bagian eksterior material komposit juga banyak di aplikasikan di beberapa bagian fuselage interior panel pesawat terbang seperti pada cabin overhead ceiling panel dan cabin side wall. Kelebihan dari material komposit sendiri ialah material komposit sampai saat ini masih menjadi material yang paling kuat dan ringan dibanding dengan jenis material konvensional, biaya produksi yang lebih murah daripada logam, dan proses manufaktur yang mudah untuk membuat bentuk streamlined pada struktur pesawat terbang. Jenis material komposit yang sering digunakan pada pesawat yaitu serat karbon dan serat kaca. Komposit dengan serat tersebut dikenal dengan kekuatan yang tinggi dan berat yang rendah menjadikanya lebih baik daripada paduan aluminium, sehingga sangat menguntungkan dalam pandangan engineering ataupun sektor bisnis dalam pemanfaatanya. Akan tetapi komposit serat tersebut memiliki beberapa kelemahan, yaitu serat tersebut sukar untuk terdegradasi secara alami, menimbulkan gatal saat bersentuhan dengan kulit manusia karena partikel partikel kaca ataupun karbon yang berukuran kecil dan kasar masuk ke pori - pori kulit, selain itu serat karbon / kaca tergolong kurang ramah lingkungan, dikarenakan sampai saat ini salah satu metode untuk mendaur ulang komposit serat karbon adalah dengan metode pirolisis, yang mana proses ini adalah dekomposisi bahan dengan proses pemanasan yang tinggi untuk memisahkan serat karbon dengan matriks atau katalis. Proses pirolisis yang sempurna seharusnya mengubah unsur karbon menjadi karbon dioksida (CO2). Tetapi tidak semua unsur karbon berhasil diubah menjadi $\mathrm{CO} 2$, dikarenakan Ketidaksempurnaan proses pemanasan, unsur karbon malah menjadik gas karbon monoksida (CO). Dua-duanya adalah gas yang beracun bagi tubuh manusia. Keberadaan kedua gas ini bisa mencemari 21\% kadar oksigen yang seharusnya dihirup oleh manusia dan bisa menimbulkan gejala awal berupa sesak nafas saat oksigen terkontaminasi oleh karbon[3]. Selain itu efek keracunan gas ini terhadap tubuh manusia tergantung pada kadar lama pemaparan terhadap tubuh manusia, Pemaparan selama 10 menit bisa mengakibatkan hilangnya kesadaran dan jika pemaparan dengan kadar tersebut berlanjut hingga 30 menit akan menyebabkan kematian.Untuk itu serat ramah lingkungan yang juga kuat diperlukan untuk menggantikan peran serat kaca ataupun karbon [4]. Pada penelitian ini penulis menggunakan serat bambu yang jumlahnya melimpah di Indonesia dengan batang yang terbentuk dari banyak ruas dan memiliki serat panjang, menjadikan bambu salah satu tumbuhan yang kuat, kokoh dan ringan untuk digunakan sebagai material penguat struktur komposit yang dapat menggantikan peran dari serat sintetis pada bagian fuselage interior panel seperti pada cabin overhead ceiling panel, karena pada bagian tersebut kekuatan yang dibutuhkan tidak sebesar pada bagian eksterior. Untuk menegetahui nilai kekuatan komposit serat bambu, maka penulis melakukan uji mekanis dan analisis deskriptif terhadap kekuatan material komposit dengan variasi jenis serat bambu apus, wulung, tutul dan petung. Limbah serat bambu yang diuji diharapkan dapat dimanfaatkan sebagai material penyusun komposit alternatif oleh industri manufaktur pesawat terbang di Indonesia, mengingat bambu yang diuji jumlahnya melimpah di Indonesia [5].

\section{Metodologi Penelitian}

Material adalah sesuatu yang disusun atau dibuat oleh bahan [6]. Material yang sifat dan karakteristiknya sangat dipengaruhi oleh jenis bahan yang digunakan adalah material komposit. Material komposit sendiri pada umumnya tersusun dari 2 fasa, yaitu matriks (pengikat) dan reinforcement (penguat). Secara umum matriks memiliki fraksi volume terbesar 
dalam struktur komposit, hal ini dikarenakan fungsi dari matriks sebagai,

a Media untuk transfer tegangan dari beban ke serat.

b Pelindung orientasi arah serat agar tetap stabil selama proses manufaktur.

c Pemisah serat.

d Pelindung serat dari pengaruh lingkungan.

Terdapat banyak jenis matriks yang dapat digunakan untuk fabrikasi material komposit, salah satunya adalah epoxy resin eposchon dan diperkuat dengan epoxy hardener eposchon yang memiliki densitas masing - masing sebesar $1,17\left(\frac{\mathrm{gram}}{\mathrm{cm}^{3}}\right)$ dan 0,92 $\left(\frac{\mathrm{gram}}{\mathrm{cm}^{3}}\right)$. matriks jenis ini memiliki kekuatan yang relatif tinggi, kekentalan dan laju alir yang relatif rendah sehingga dapat mencegah ketidaksejajaran serat selama proses manufaktur, kemampuan menguap selama pengeringan rendah dan laju penyusutan yang rendah.Sedangkan reinforcement (penguat) biasanya dalam bentuk serat yang fungsinya untuk memperkuat bahan komposit secara keseluruhan atau sebagai penahan beban utama struktur komposit. Karena mulanya tegangan yang diberikan pada struktur komposit diterima oleh matriks dan akan diserap oleh serat sampai pembebanan maksimum, maka serat harus memiliki sifat mekanis tegangan dan modulus elastisitas yang lebih tinggi dari matriks. Melalui pancampuran kedua fase material yang berbeda tersebut akan muncul material baru dengan sifat mekanis yang berbeda dari material pembentuknya.

Secara umum komposit berpenguat serat dibagi menjadi 2 jenis yaitu,

a. Serat sintetis

Adalah serat yang dibentuk melalui proses gabungan dari produksi manufaktur yang berbeda, dan tiap - tiap unsur penyusun serat digabungkan melalui teknik pemisahan atau pembentukan serat tertentu. Serat sintetis secara umum terbuat dari polimer yang dipolimerisasi dan menghasilkan lelehan polimer, kemudian dari hasil ini dilakukan proses spinning untuk membentuk serat dengan geometri yang sesuai dengan kebutuhan yang dinginkan, seperti panjang dan diameter serat yang selaras atau satu ukuran. Contoh dari serat jenis ini adalah serat karbon dan serat kaca. Material komposit dengan serat ini di gunakan secara masif pada struktur pesawat terbang dengan alasan material ini lebih kuat dan ringan daripada beberapa material jenis lain seperti aluminium dan sebagainya. Penggunaan material komposit dengan serat sintetis pada bagian pesawat terbang sendiri secara umum difokuskan pada bagian yang membutuhkan kekuatan besar seperti pada struktur penyusun fuselage ( badan pesawat terbang ), vertical stabilizer, horizontal stabilizer, wing dan struktur sejenis lainya. Selain pada struktur tersebut, material komposit dengan serat sintetis secara masif juga diaplikasikan pada struktur interior pesawat terbang seperti struktur fuselage interior yang terletak dibagian dalam badan pesawat terbang. Bagian ini meliputi komponen floor, cabin overhead ceiling panels, cargo liniers, overhead stowage bins, windows surround, lavatory modules, galleys, bulkhead/class dividers dan komponen sejenis lainya. Komponen - komponen tersebut secara umum menggunakan material komposit serat sintetis thermoset prepregs, honeycomb core dan advanced thermoplastic. Komposit serat kaca tipe - E dengan pengikat matriks justus 157 yang disusun dengan orientasi serat $0^{\circ}$ dengan fraksi voulume serat $40 \%$ memiliki kekuatan tarik sebesar $101.008 \frac{\mathrm{N}}{\mathrm{mm}^{2}}$. Kekuatan bending komposit serat kaca dengan matriks polyester UPE dan arah orientasi serat $0^{\circ}$, lalu diuji menggunakan metode three point bending dan didapat nilai tegangan bending sebesar 148 $\frac{N}{m m^{2}}[7]$.

b. Serat Alam

Yaitu jenis serat yang diproduksi dari bahan alam seperti tumbuhan dan hewan, diperlukan perlakuan khusus untuk membentuk gemoetri serat pada jenis ini, dikarenkan geometri serat jenis ini terbatas pada panjang atau luas dari bahan yang ditinjau dan tidak sebaik 
atau seragam dari jenis serat sintetis yang ukuranya dapat dibentuk sesuai keinginan. Material komposit yang berpenguat serat terutama serat alam merupakan material alternatif yang memiliki banyak keunggulan dalam hal ekonomis, ramah lingkungan dan ringan bila dibandingkan dengan material alternatif lain termasuk serat karbon ataupun kaca.

Contoh : serat bambu, serat kelapa, serat kayu, dan serat alam lainya.

Berdasarkan pola susun / penempatanya, serat komposit dibedakan menjadi beberapa jenis, yaitu :

- Continuous Fibre Composite atau susunan serat panjang dan sejajar matriks.

- Woven Fibre Composite (bi-dirtectional) atau pola susun serat anyam.

- Discontinuous Fibre Composite (chopped fibre composite) adalah pola susun serat pendek dengan arah beraturan (aligned), tidak beraturan (Random) dan Off-axis aligned.

- Hybrid fibre composite adalah gabungan antara tipe serat lurus dengan serat acak.

- Kualitas serat, khususnya serat alam.

Pada struktur komposit dapat di tinjau melalui konsentrasi fraksi volume, bentuk, ukuran, orientasi dan proses pengolahan serat. Komposit dengan susunan serat panjang lebih kuat dibanding serat pendek dikarenakan serat panjang dapat meneruskan beban maupun tegangan dari titik tegangan ke arah serat yang lain .

Ukuran serat juga berpengaruh, menggunakan serat alam yang berdiameter kecil sebagai penguat komposit menunjukkan kekuatan tarik dan ikatan antara serat dan matriks yang relatif lebih baik. Serat alam memiliki kandungan lignin yang menyebabkan daya rekat dengan matriks menjadi rendah dan diperlukan proses khusus untuk menguranginya, salah satu caranya yaitu diberi perlakuan alkali, pengaruh perlakuan alkali terhadap pemisahan serat dapat ditinjau dari salah satu penelitian yang pernah dilakukan oleh Kuncoro Diharjo (2006) serat alam yang diberi perlakuan alkali $(\mathrm{NaOH}) 5 \%$ selama 2 jam memiliki kekuatan yang lebih optimum dibanding dengan waktu perlakuan 0,4 dan 6 jam.

Volume serat juga mempengaruhi ketangguhan suatu spesimen. Variasi fraksi volume serat dapat mempengaruhi kekuatan komposit. Nilai kekuatan komposit akan optimum (semakin meningkat) jika diberi fraksi volume serat $25 \%$ sampai $45 \%$, tetapi setelah $45 \%$ kekuatan komposit akan menurun, hal ini diakibatkan semakin menurunya fraksi volume matriks menyebabkan matrik tidak akan mampu mengikat serat satu sama lain dengan baik. Akibatnya pada saat diberikan pembebanan, beban tidak terdistribusi dengan maksimal karena ikatan antara serat yang lemah Sehingga pengaruh komposisi serat dapat di simpulkan, semakin banyak volume serat maka kekuatan komposit semakin tinggi, akan tetapi bila terlalu banyak serat yang tidak seimbang dengan volume matriknya, maka kekuatannya juga akan melemah.

Kemudian orientasi arah serat menjadi tinjaun utama dalam kekuatan struktur komposit, berbagai penelitian dilakukan terhadap pengaruh orientasi arah serat terhadap kekuatan komposit yang melakukan perbandingan kekuatan material komposit dengan orientasi serat $0^{\circ}$ dan $90^{\circ}$, dan dibuktikan bahwa serat dengan orientasi $0^{\circ}$ lebih kuat karena karena beban uji tarik spesimen arah vertikal akan diterima langsung oleh resin dan selanjutnya didistribusikan keseluruh permukaan searah dengan orientasi serat.Bambu merupakan tanaman yang mudah ditemukan di daerah tropis terutama di Indonesia. Bambu memiliki bentuk batang yang terdiri dari serat panjang dan beruas. Serat bambu secara mekanik mempunyai kekuatan tarik yang tinggi (140-800 MPa), dan modulus elastisitas yang tinggi (33 GPa) dengan densitas yang rendah $0,6-0,8 \mathrm{~g} / \mathrm{cm} 3$. Sehingga kekuatan dan modulus elastis jenis serat bambu sangat tinggi dan sebanding dengan serat kaca. Hal ini lah yang dapat membuat bambu merupakan suatu material yang kokoh, kuat sekaligus ringan untuk dijadikan sebagai material penyusun komposit serat alam. Sifat mekanis variasi jenis serat bambu yang digunakan untuk membentuk material komposit terdapat pada tabel 1. 
Tabel 1. Sifat mekanis serat bambu apus, wulung, tutul dan petung

\begin{tabular}{|c|c|c|c|}
\hline $\begin{array}{c}\text { Tipe serat } \\
\text { bambu }\end{array}$ & $\begin{array}{c}\text { Kerapatan } \\
\left(\frac{\mathbf{g r a m}}{\mathbf{c m}^{\mathbf{3}}}\right)\end{array}$ & $\begin{array}{c}\text { Tegangan Tarik } \\
\left(\frac{\boldsymbol{k g}}{\mathbf{c m}^{\mathbf{2}}}\right)\end{array}$ & $\begin{array}{c}\text { Tegangan Bending } \\
\left(\frac{\mathbf{k g}}{\mathbf{c m}^{\mathbf{2}}}\right)\end{array}$ \\
\hline Apus & 0.714 & 712.89 & 60126 \\
\hline Wulung & 0.65 & 439.94 & 85170 \\
\hline Petung & 0.71 & 2324.95 & 86550 \\
\hline Tutul & 0.62 & 1872.77 & 63631 \\
\hline
\end{tabular}

Pada penilitian ini dilakukan pengujian tarik dan bending untuk menyimpulakan kekuatan material komposit serat bambu secara visual. Secara umum pengujian tarik dilakukan untuk mengetahui tegangan, regangan dan modulus elastisitas bahan dengan memberikan beban tarik secara vertikal, sedangkan pengujian bending adalah proses pengujian dengan penekanan terhadap bahan secara horizontal. Kekuatan bending atau kekuatan lengkung adalah tegangan bending terbesar yang dapat diterima akibat pembebanan luar tanpa mengalami deformasi yang besar atau kegagalan. Besar kekuatan bending tergantung pada jenis material dan pembebanan. Akibat pengujian bending, bagian atas spesimen mengalami tekanan, sedangkan bagian bawah aka mengalami tegangan tarik. Dalam material komposit, kekuatan tekannya akan lebih tinggi dari pada kekuatan tariknya. Semakin tinggi nilai kekuatan lengkung dan tarik menunjukkan serat terikat sempurna oleh matrik. Sehingga seluruh pembebanan ditanggung secara merata oleh semua serat sebagai satu kesatuan yang artinya setiap serat dalam komposit menerima beban yang sama.Hasil dari pengujian bending dan tarik adalah grafik hubungan antara beban terhadap elongasi, hasil tersebut dapat di olah untuk menjadi nilai tegangan tarik dan bending melalui persamaan berikut :

a. Tegangan Tarik

$$
\sigma=\frac{F}{A}
$$

b. Tegangan bending

$$
\sigma=\frac{3 F L}{2 b d^{2}}
$$

c. Regangan

$$
\varepsilon=\frac{l_{1}-l_{0}}{l_{0}} \times 100 \%
$$

Dimana :

$$
\begin{aligned}
& \mathrm{F}=\text { Nilai gaya terhadap permukaan bahan }(\mathrm{N}) . \\
& \mathrm{A}=\text { Luas penampang bahan }\left(\mathrm{mm}^{2}\right) \\
& \mathrm{L}=\text { Panjang jarak tumpuan }(\mathrm{mm}) . \\
& \mathrm{b}=\text { Lebar spesimen }(\mathrm{mm}) . \\
& \mathrm{d}=\text { Tebal spesimen }(\mathrm{mm}) \\
& l_{0}=\text { Panjang sepesimen sebelum pembebanan. } \\
& l_{1}=\text { Panjang spesimen setelah pembebanan. }
\end{aligned}
$$

Berdasarkan definisi dan tinjauan pustaka yang dijelaskan di bab sebelumnya, maka metode penelitian pada penelitian ini adalah eksperimental dengan proses fabrikasi material komposit menggunakan variasi serat penguat bambu apus, wulung, tutul dan petung dengan pola serat panjang, kemudian serat diberi pengikat matrik eposchon dengan fraksi volume serat dan matrik masing - masing sebesar $25 \%$ dan $75 \%$. Sebelumnya serat bambu tersebut diberi perlakuan alkali dengan $\mathrm{NaOH}$ sebanyak 5\% dengan lama perendaman 2 jam, lalu serat disusun dengan arah orientasi sumbu $0^{\circ}$. Kemudian metode fabrikasi yang digunakan adalah hand lay up.Proses uji tarik dilakukan dengan cara ujung-ujung sampel dikaitkan pada alat uji universal testing machine, kemudian beban penarik dipasang pada satuan beban kgf, lalu 
sampel ditarik dengan kecepatan tertentu hingga putus, kemudian besar beban penarik maksimum (Fmax) diikuti dengan perubahan panjang sampel ditampilkan dalam bentuk grafik. Spesimen material komposit untuk pegujian tarik dibentuk sesuai standar ASTM D638 tipe 1.

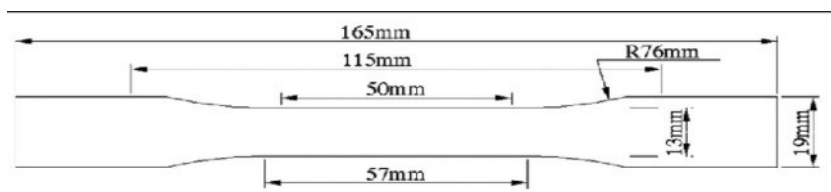

Gambar 1. Spesimen uji tarik ASTM D638 tipe 1.

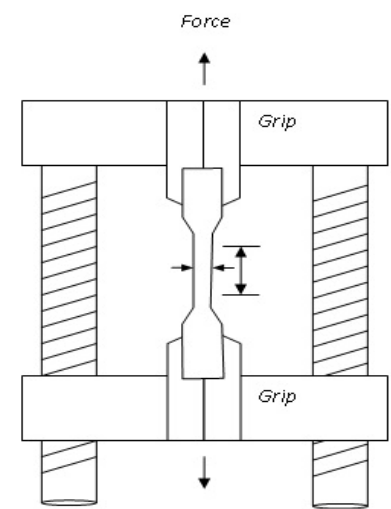

Gambar 2. Skema proses pengujian tarik.

Pengujian bending dilakukan dengan menggunakan alat Universal Testing Machine dengan metode three point bending. Spesimen diberi beban secara horizontal terhadap point point tumpuan untuk mendapatkan data berupa kekuatan lengkung (bending) material. Uji kekuatan bending dilakukan untuk mengetahui tegangan bending terbesar yang dapat diterima akibat pembebanan luar tanpa mengalami deformasi yang besar atau kegagalan. Spesimen material komposit untuk pegujian tarik dibentuk sesuai standar ASTM D790.

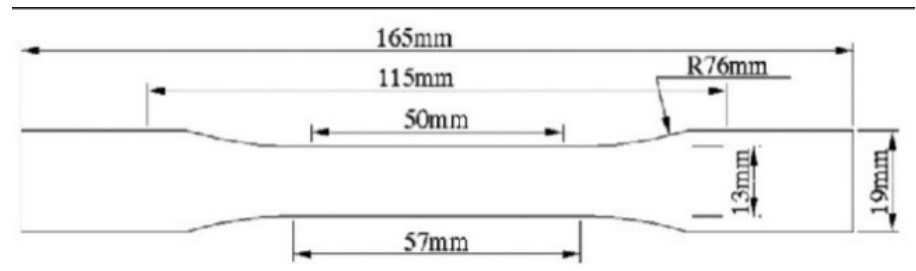

Gambar 3 Skema proses pengujian bending

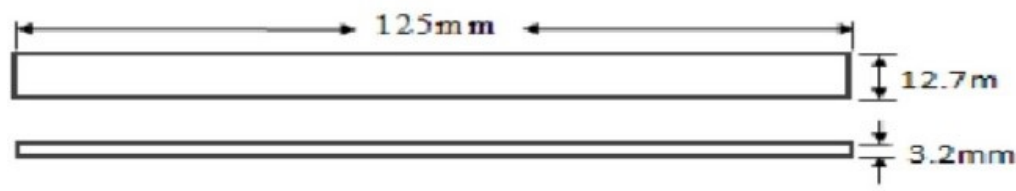

Gambar 4 Spesimen uji bending ASTM D790

\section{Hasil Penelitian}

Data hasil pengujian tarik maka di dapat nilai tegangan yang terjadi pada pembebanan maksimal bahan terdapat pada tabel 2 
Tabel 2. Nilai pembebanan yang terjadi pada pengujian tarik dimasing - masing jenis serat

\begin{tabular}{|l|c|c|c|c|c|}
\hline $\begin{array}{c}\text { Jenis } \\
\text { Bumbu }\end{array}$ & $\begin{array}{c}\text { Beban } \\
\text { Percobaan 1 } \\
\text { (Kgf) }\end{array}$ & $\begin{array}{c}\text { Beban } \\
\text { Percobaan 2 } \\
\text { (Kgf) }\end{array}$ & $\begin{array}{c}\text { Beban } \\
\text { Percobaan 3 } \\
\text { (Kgf) }\end{array}$ & $\begin{array}{c}\text { Beban } \\
\text { Percobaan 4 } \\
\text { (Kgf) }\end{array}$ & $\begin{array}{c}\text { Beban Rata- } \\
\text { Rata (Kgf) }\end{array}$ \\
\hline Patung & 442,650 & 560,373 & 342,943 & 446,749 & 448,178 \\
\hline Wulung & 183,462 & 172,060 & 145,338 & 293,007 & 198,466 \\
\hline Apus & 353,769 & 222,949 & 196,601 & 434,479 & 301,949 \\
\hline Tutul & 137,999 & 229,271 & 241,074 & 655,022 & 333,341 \\
\hline
\end{tabular}

Kemudian nilai rata - rata beban yang terjadi pada masing - masing jenis serat bambu dikonversi ke nilai gaya $(\mathrm{N})$.

Tabel 3. Nilai tegangan tarik pada masing - masing jenis serat

\begin{tabular}{|l|c|c|c|c|}
\hline Jenis Bumbu & Nilai Gaya (N) & $\begin{array}{c}\text { Luas permukaan } \\
\text { bahan } \mathbf{( m m}^{\mathbf{2}} \mathbf{)}\end{array}$ & $\begin{array}{c}\text { Nilai Tegangan } \\
\mathbf{N} / \mathbf{~ m m}^{\mathbf{2}}\end{array}$ & $\begin{array}{c}\text { Nilai } \\
\text { Regangan }\end{array}$ \\
\hline Patung & 4396,634 & 39 & 112,734 & 0,63 \\
\hline Wulung & 1946,959 & 39 & 49,922 & 0,45 \\
\hline Apus & 2962,125 & 39 & 75,951 & 0,42 \\
\hline Tutul & 3270,081 & 39 & 83,848 & 0,44 \\
\hline
\end{tabular}

Data hasil pengujian bending untuk nilai tegangan yang terjadi pada pembebanan maksimal bahan.

Tabel 4 Nilai pembebanan yang terjadi pada pengujian tarik di masing - masing jenis serat

\begin{tabular}{|l|c|l|l|l|l|}
\hline $\begin{array}{c}\text { Jenis } \\
\text { Bumbu }\end{array}$ & $\begin{array}{c}\text { Beban } \\
\text { Percobaan 1 } \\
\text { (Kgf) }\end{array}$ & $\begin{array}{c}\text { Beban } \\
\text { Percobaan 2 } \\
\text { (Kgf) }\end{array}$ & $\begin{array}{c}\text { Beban } \\
\text { Percobaan 3 } \\
\text { (Kgf) }\end{array}$ & $\begin{array}{c}\text { Beban } \\
\text { Percobaan 4 } \\
\text { (Kgf) }\end{array}$ & $\begin{array}{c}\text { Beban Rata- } \\
\text { Rata (Kgf) }\end{array}$ \\
\hline Patung & 28,644 & 20,647 & 24,667 & 22,992 & 24,242 \\
\hline Wulung & 21,364 & 16,933 & 18,998 & 25,852 & 20,801 \\
\hline Apus & 20 & 24,279 & 25,993 & 22,788 & 23,212 \\
\hline Tutul & 23,765 & 26,934 & 28,855 & 26,395 & 26,487 \\
\hline
\end{tabular}

Kemudian nilai rata - rata beban yang terjadi pada masing - masing jenis bambu dikonversi ke nilai gaya.

Tabel 5 Nilai tegangan tarik pada masing - masing jenis serat.

\begin{tabular}{|c|c|c|c|c|c|}
\hline Jenis Bumbu & $\begin{array}{c}\text { Nilai Gaya } \\
(\mathbf{N})\end{array}$ & $\begin{array}{c}\mathbf{L} \\
(\mathbf{m m})\end{array}$ & $\begin{array}{c}\mathbf{b} \\
\mathbf{( m m})\end{array}$ & $\begin{array}{c}\mathbf{D} \\
(\mathbf{m m})\end{array}$ & $\begin{array}{c}\text { Nilai Tegangan } \\
\mathbf{N} / \mathbf{m m}^{\mathbf{2}}\end{array}$ \\
\hline Patung & 237,818 & 80 & 12,7 & 3 & 249,678 \\
\hline Wulung & 204,060 & 80 & 12,7 & 3 & 214,236 \\
\hline Apus & 227,717 & 80 & 12,7 & 3 & 239,073 \\
\hline Tutul & 259,839 & 80 & 12,7 & 3 & 272,797 \\
\hline
\end{tabular}

Setelah didapat data tegangan tarik dan bending dalam tabel diatas diketahui bahwa material komposit dengan serat bambu petung memilki kekuatan tarik yang paling besar dari 3 jenis serat bambu lainya, hal ini diakibatkan oleh sifat mekanis serat bambu petung berupa nilai kuat tarik yang paling tinggi dari 3 varian bambu lainya dengan kondisi sifat mekanis matriks yang sama, hal ini membuktikan bahwa kualitas serat merupakan peran utama dalam 
keberhasilan fungsi material komposit, karena seperti diketahui bahwa serat merupakan unsur yang berfungsi sebagai penahan beban, sehingga semakin baik kandungan serat dalam komposit akan berpotensi memberikan dukungan yang lebih pada komposit untuk menahan beban. Pada pengujian bending serat bambu tutul memiliki kekuatan lengkung paling baik diantara 3 varian lainya, hal ini bisa diakibatkan oleh kualitas serat bambu tutul yang terikat paling sempurna oleh matrik. Sehingga seluruh pembebanan ditanggung secara merata oleh semua serat sebagai satu kesatuan yang artinya setiap serat dalam komposit menerima beban yang sama.

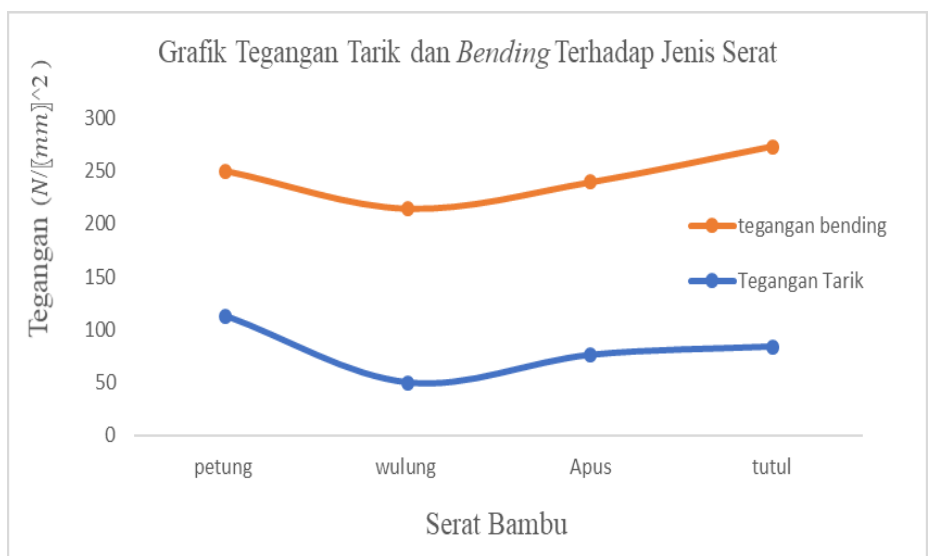

Gambar 5. grafik tegangan tarik dan bending terhadap jenis serat

\section{Kesimpulan}

Pada penelitian ini didapat nilai tegangan tarik $\left(\frac{\mathrm{N}}{\mathrm{mm}^{2}}\right)$ pada komposit serat bambu petung, wulung, apus dan tutul masing-masing sebesar 112.73, 49.92, 75.95, 83.84, diikuti dengan nilai regangan masing - masing serat sebesar $0.63,0.45,0.42,0.44$. Kemudian nilai tegangan bending $\left(\frac{\mathrm{N}}{\mathrm{mm}^{2}}\right)$ yang terjadi pada komposit serat bambu petung, wulung, apus dan tutul masing-masing sebesar 249.678 , 214.236, 239.073 , 272.797.Bagian cabin overhead ceiling panel pada struktur pesawat terbang modern Secara umum menggunakan material komposit sintetis dengan penguat serat kaca yang memiliki kekuatan tarik dan bending masing - masing sebesar $101.008 \frac{\mathrm{N}}{\mathrm{mm}^{2}}$ dan $148 \frac{\mathrm{N}}{\mathrm{mm}^{2}}$. Melalui penelitian yang dipaparkan pada karya tulis ini, Kekuatan tersebut lebih rendah dari kekuatan komposit serat bambu petung yang masing masing sebesar $112.734 \frac{\mathrm{N}}{\mathrm{mm}^{2}}$, dan $249.678 \frac{\mathrm{N}}{\mathrm{mm}^{2}}$. Kemudian komposit serat bambu juga lebih ekonomis dan ramah lingkungan dengan tidak menimbulkan gatal saat mengenai kulit manusia dan tidak menimbulkan gas CO atau CO2 yang semasif serat karbon saat didaur ulang. Dengan alasan tersebut dapat disimpulkan bahwa komposit serat bambu terutama bambu petung sangat memungkinkan untuk menggantikan peran dari penggunaan material komposit serat sintetis pada bagian cabin overhead ceiling panel pesawat terbang.

\section{Daftar Pustaka}

[1] Abdullah, T, E., 2013, 'A Study of Bending Properties of Unsaturated Polyester/Glass Fiber Reinforced Composites', Journal of Al-Nahrain University, Baghdad.

[2] Gunara, M, D., Prasetyo, A, W., Banowati, L., 2017, 'Analisis Perbandingan Kekuatan Tarik Orientasi Undirectional $0^{\circ}$ dan $90^{\circ}$ Pada Struktur Komposit Serat Mendong dengan Menggunakan Epoksi Bakelite EPR 174'. Infomatek, Bandung.

[3] Noor, A. F., Khairurrijal, K., Sukimo, S., 2009, 'Kajian Pembuatan Nanotube Karbon dengan Menggunakan Metode Spray Pyrolysis', Jurnal Nanosais \& Nanoteknologi. 
Bandung.

[4] Nurhidayah, N., 2016,Pengaruh Variasi Fraksi Volume Serat Daun Lontar (Borassus Flabelifer) Terhadap Sifat Fisik dan Sifat Mekanik Komposit Polyester, Universitas Airlangga, Surabaya.

[5] Rios, L. D. T. E., 2014, Polymer Composite Materials Based on Bamboo Fibres, KU Leuven, Belgium.

[6] Schwart, M. M., 1984, Composite Materials Handbook, Mc Graw-Hill Book Co., New York.

[7] Sutardi, R. S., Nadjib, N., Jasni, M. M., Sulastiningsih, I. M., Suprapti, S. K. S., Abdurrahman., Basri, E., 2015, Informasi Sifat Dasar dan Kemungkinan Penggunaan 10 Jenis Bambu, Pusat Penelitian dan Pengembangan Hasil Hutan Badan Penelitian, Pengembangan dan Inovasi Kementerian Lingkungan Hidup dan Kehutanan, Bogor. 